TELEIOS: Jurnal Teologi dan Pendidikan Agama Kristen

Sekolah Tinggi Teologi Transformasi Indonesia

ISSN 2798-0642 (Online), 2798-1797 (Print)

Volume 1, Nomor 2, Desember 2021 (130-143)

DOI: 10.53674/teleios.v1i2.34

stttransformasi-indonesia.ac.id/e-journal/index.php/teleios/index

\title{
Analisis Kritis terhadap Konsep Kristologi Penganut Kristen Tauhid
}

\author{
${ }^{1}$ Herry Sonya Corneles, ${ }^{2}$ Jefry Yopie Afner Suak, ${ }^{3}$ Veydy Yanto Mangantibe \\ ${ }^{1,2,3}$ Sekolah Tinggi Teologi Yerusalem Baru Manado \\ 1'herrykorneles17@gmail.com, jefrysuak102@gmail.com,vmangantiber90@gmail.com
}

\begin{abstract}
Abstrak:
Artkel ini membahas konsep kristologi penganut krsiten tauhid. Persoalan doktrin Kristologi, khususnya tentang hubungan antara natur keilahian dan natur keinsanian Yesus Kristus sudah ada sejak abad mula-mula, sehingga gereja merumuskan rumusan Chalcedon pada konsili Chalcedon yang diadakan tahun 451. Tetapi persoalan Kristologi tetap berlanjut meskipun gereja sudah memiliki rumusan Chalcedon tersebut. Salah satu ajaran yang menentang Trinitas dan doktrin keilahian Yesus Kristus adalah unitarianisme, yang muncul pada abad reformasi. Paham unitarianisme merupakan paham yang meyakini bahwa hanya ada satu Allah saja, baik eksistensi maupun persona. Dalam ajaran tentang Kristus, paham ini lebih menekankan kemanusiaan Yesus Kristus dan menolak natur keilahian Yesus Kristus. Dibuktikan pada bagian Alkitab bahwa Yesus adalah Allah dalam beberapa cara. Karena Kristus benar-benar tokoh yang pernah hadir dalam sejarah dunia ini. Penulisan ini menggunakan metode penelitian deskriptif dengan pendekatan kajian literatur, sehingga diperoleh data tentang latar belakang sejarah dan ajaran penganut Kristen Tauhid, presuposisi penganut Kristen Tauhid, pokokpokok pemikiran Kristologis penganut Kristen Tauhid, analisis terhadap konsep Kristologi penganut Kristen Tauhid dan implikasinya bagi Theologia Kristen.
\end{abstract}

Kata Kunci: Analisis Kritis, Konsep Kristologi, Kristen Tauhid

\begin{abstract}
:
This article discusses the christology concept of monotheistic Christians. The issue of the doctrine of Christology, especially regarding the relationship between the divine nature and the human nature of Jesus Christ, has existed since the early centuries, so the church formulated the Chalcedon formula at the Chalcedon council which was held in 451. But the Christological problem continued even though the church already had the Chalcedon formula. One of the teachings that opposed the Trinity and the doctrine of the divinity of Jesus Christ was unitarianism, which emerged in the Reformation century. Unitarianism is an understanding that believes that there is only one God, both existence and person. In the teachings of Christ, this understanding emphasizes the humanity of Jesus Christ and rejects the divinity of Jesus Christ. This writing uses a descriptive research method with a literature review approach, in order to obtain data on the historical background and teachings of monotheistic Christians, presuppositions of monotheistic Christians, the main points of Christological thoughts of monotheistic Christians, analysis of the concept of Christology of monotheistic Christians and their implications for Christian Theology.
\end{abstract}

Keywords: Critical Analysis, Christological Concepts, Monotheistic Christian 


\section{Pendahuluan}

Kristus merupakan pusat pemberitaan Alkitab dan pengharapan umat-Nya. Tanpa Kristus, kekristenan tidak mempunyai makna apapun. Sebab pemahaman seseorang akan tokoh Kristus akan sangat mempengaruhi iman dalam kehidupannya ${ }^{1}$. Rasul Petrus dalam suratnya menubuatkan ciri utama penyimpangan doktrin Kristologi, yakni akan munculnya guru-guru palsu di dalam gereja yang mirip dengan nabi-nabi palsu di zaman Israel dahulu. Para guru palsu tersebut diam-diam akan menyelundupkan pengajaran sesat yang membinasakan (II Pet. 2:1-2). Ciri pengajaran tersebut adalah "menyangkal penguasa yang menebus mereka", yang akibatnya mendatangkan kebinasaan atas diri mereka sendiri. Ciri-ciri penyimpangan doktrin Kristologi juga dijelaskan oleh rasul Yohanes dalam I Yoh 2:22-23; 4:3; II Yohanes 7. Hal ini menyangkut dua pokok, yakni: Pertama, menyangkal bahwa Yesus adalah Kristus dan penyangkalan terhadap doktrin Tritunggal. Kedua, penolakan terhadap kemanusiaan Yesus Kristus atau penolakan terhadap doktrin inkarnasi ${ }^{2}$.

Melalui sejarah gereja, dapat dicermati bahwa yang menjadi esensi permasalahan dan perpecahan jemaat pada masa itu berkisar mengenai posisi Yesus Kristus di dalam Trinitas, bahwa Yesus Kristus sebagai Anak Allah bersifat konsubtansi atau sehakikat dengan Bapa dan karena itu Dia sungguh Allah sejati. Selanjutnya, permasalahan dari Kristologi adalah lingkup dan karakteristik dari relasi natur keilahian dan keinsanian Yesus Kristus. Pada satu pihak, ada pengajaran Kristologi yang menekankan kemanusiaanNya. Sedangkan, ada pihak lain yang menekankan KeilahianNya dalam pengajaran Kristologinya ${ }^{3}$.

Melalui konsili Chalcedon pada tahun 451, yang merupakan salah satu bentuk dari respon para bapa-bapa gereja, maka ditetapkan bahwa pandangan-pandangan tersebut adalah salah dan tetap mempertahankan kesatuan dalam pribadi Kristus dan dua natur yang ada dalam diriNya, bahwa keilahianNya dan kemanusiaanNya tidak bercampur dan tidak berubah serta tidak terbagi dan tidak terpisah. Walaupun rumusan Chalcedon bukanlah penjelasan secara positif tentang bagaimana relasi keilahian dan kemanusiaan Yesus Kristus, namun gereja memberikan batasan-batasan bagaimana relasi itu tidak boleh diartikan. Setelah gereja memiliki rumusan Chalcedon, perdebatan tentang Kristologi tetap berlanjut sampai saat ini. Salah satu pandangan yang muncul dan menolak Trinitas serta keilahian Yesus Kristus adalah unitarianisme, yang muncul setelah perlawanan Marthin Luther terhadap ajaran gereja Roma Khatolik. Ajaran yang dipelopori oleh Faustus Socinus bersama pamannya, Laelus Socinus, dan Michael Servetus ini mengklaim bahwa doktrin Trinitas tidak punya dasar dalam Alkitab dan tidak masuk akal. Pada akhirnya, penganut unitarian ini dicap sebagai bidat, dan kemudian banyak yang hijrah ke Polandia dan Transylvania di mana kepercayaan unitarianisme diterima.

Saat ini di Indonesia juga telah muncul penganut unitarianisme yang menamakan dirinya sebagai penganut Kristen Tauhid. Keberadaan penganut Kristen Tauhid ini sudah diakui oleh Bimas Kristen Departemen Agama RI pada tahun 2000 sebagai salah satu aliran

\footnotetext{
${ }^{1}$ Leti Yulita Samai and Hendi Hendi, "Personalitas Yesus Dan Kritik Terhadap Nestorius: Analisis Ibrani 4: 12-14," SHAMAYIM: Jurnal Teologi dan Pendidikan Kristiani 2, no. 1 (2021): 14-23.

2 Daniel Tumbel, “Kristologi Dalam Injil Sinoptik," Journal Kerusso 1, no. 2 (2016): 42-56.

${ }^{3}$ Maria Widiastuti, "Pemahaman Kristologi Bagi Guru PAK," Pendidikan Agama Kristen Vol.7 No.3 (2020): 93.
} 
dari agama Kristen. Pendiri sekaligus tokoh utama penganut Kristen Tauhid yaitu Tjahjadi Nugroho, oleh karena itu Tjahjadi Nugroho menjadi ketua sinode dan mengaku sebagai ketua asosiasi pendeta Indonesia. Dalam tulisan para pelopor penganut Kristen Tauhid, secara eksplisit mereka mengaku memiliki paham unitarianisme yang hanya mengakui keesaan Tuhan dan menolak Trinitas yang dipercayai umat Kristen pada umumnya. Allah yang disembah ialah Allah dari Yesus Kristus, yang juga Allah Muhammad S.A.W, Ibrahim, Ismail, Ishak dan Yakub, serta para nabi lainnya.

Penulis mencermati bahwa ada kecenderungan di kalangan mereka untuk menjadikan penganut Kristen Tauhid sebagai penganut unitarian yang khas Indonesia, yaitu dengan berusaha untuk mensintesakan ajaran Kristen Tauhid dengan ajaran agama Islam yang dianut oleh sebagian besar warga Indonesia, khususnya konsep tentang Allah. Hal ini terlihat dalam buku-buku karangan para tokoh penganut Kristen Tauhid yang sering menggunakan ayat-ayat Al-Qur'an untuk mendukung asumsi mereka. Penganut Kristen Tauhid banyak menganjurkan keterbukaan termasuk terhadap liberalisme maupun terhadap agama Islam, dan mempromosikan toleransi beragama. Berkenaan dengan hal ini, Lumintang menuliskan: Eksistensi agama, dan kerukunan antar umat beragama ditengah kemajemukan dan keunikan agama, selain didukung dan dijamin oleh undang-undang juga ditopang oleh kesadaran adanya toleransi. Toleransi antar umat beragama di Indonesia memang bertumbuh subur, dan untuk melestarikan serta meningkatkan toleransi itu, maka para tokoh-tokoh agama terus mengadakan pertemuan-pertemuan untuk berdialog. Dalam usaha mempromosikan toleransi beragama antar agama Kristen dengan agama Islam, Donald menyatakan bahwa ada perbedaan secara ritual atau syariat dalam agama Kristen dengan agama Islam, tetapi hakikat dari agama-agama Ibrahimik tetap sama, yaitu menyembah Allah yang esa, tauhid.

Menurut penulis, sikap ini telah merubah arti dan hakikat masing-masing agama, termasuk merubah arti dan hakikat agama Kristen. Oleh karena itu, banyak pihak, baik dari kalangan Kristen maupun Muslim yang sedang menyoroti perkembangan penganut Kristen Tauhid yang dianggap sebagai gerakan arus bawah yang benar-benar bisa menggoyahkan pondasi kepercayaan iman dasar kekristenan. Penganut Kristen Tauhid dikenal melalui bukubuku yang ditulis oleh para pelopor gerakan ini, dan juga kegiatan mereka yang rajin melalui diskusi dan hadir dalam forum-forum antar agama dan debat terbuka. Mereka cepat terkenal karena sikap mereka yang secara frontal menyerang doktrin Trinitas. Pengajaran mereka terutama ditulis melalui buku-buku karya Tjahjadi Nugroho, Frans Donald, dan Ellen Kristi. Dalam tulisan para pelopor penganut Kristen Tauhid tersebut, mereka menyerang doktrin Trinitas dan keilahian Yesus Kristus dengan mengklaim bahwa Yesus Kristus bukanlah Allah, melainkan hanyalah utusan Allah. Para pelopor penganut Kristen Tauhid mengklaim bahwa Yesus Kristus sendiri mengajar tentang ketauhidan Allah, BapaNya, kepada para rasul sehingga mereka percaya bahwa jemaat Kristen mula-mula beriman kepada Allah yang esa, dan Ketauhidan itu berkaitan erat dengan iman monotheisme Abraham.

Dari apa yang dikemukakan di atas, penulis mencermati bahwa penganut Kristen Tauhid mau kembali kepada agama monotheisme Abraham yang dipercayai oleh umat Yahudi. Monotheisme yang tidak menyekutukan Allah sehingga pada akhirnya menjadikan Yesus sekedar ciptaan yang lebih rendah dari Yahweh. Ellen Kristi, tokoh penganut Kristen Tauhid lainnya, menyatakan bahwa terkait dengan keberakarannya dalam tradisi Judeo-Kristen, ada 
beberapa sikap dasar tradisi tersebut yang diwarisi oleh iman penganut Kristen Tauhid. Pertama, seorang penganut Kristen Tauhid memilih untuk meletakkan dasar imannya dalam kitab suci Judeo-Kristen (the Bible), baik Perjanjian Lama maupun Perjanjian Baru. Sikap ini diambil tanpa merendahkan makna Kitab Suci agama-agama lain. Kedua, seorang penganut Kristen Tauhid memandang dan menghargai tinggi pribadi Yesus Kristus.

Penulis mencermati bahwa ada distorsi dalam pengakuan dan penghargaan penganut Kristen Tauhid terhadap pribadi dan kreasi Yesus Kristus. Menurut mereka, Allah Bapa mengutus Yesus Kristus supaya manusia bisa mendapat hikmat pengetahuan untuk memperoleh hidup kekal dan tidak binasa karena Yesus Kristus menunjukkan pada umat manusia suatu kunci untuk mendapatkan hidup yang kekal itu. Donald menyatakan bahwa Yesus sendiri mengajarkan bahwa kunci untuk hidup kekal hanya ada dua. Pertama, kenal satu-satunya Allah yang benar. Kedua, kenal Yesus utusan Allah untuk mengenal Allah dengan benar, oleh sebab itu Yesuslah satu-satunya jalan dan pengantara untuk manusia bisa mencapai Allah. Dari pandangan ini, penulis mencermati bahwa penganut Kristen Tauhid melihat pribadi Yesus Kristus hanya sebagai utusan Allah Bapa dan bukan Pribadi kedua Allah Tritunggal yang berinkarnasi menjadi manusia, atau dengan kata lain, penganut Kristen Tauhid menolak kesatuan kedua natur Yesus Kristus. Penganut Kristen Tauhid mengaku sebagai aliran Kristen yang bertumpu pada Alkitab Kristen, namun mengapa mereka menolak keyakinan Trinitarian yang mengakui keilahian Yesus Kristus dan yang dipercayai oleh umat Kristen pada umumnya? Dari berbagai pengajarannya, terlihat bahwa penganut Kristen Tauhid merupakan penerus kembali semangat anti Trinitas paham Gnostik (abad ke-2 dan 3), Arianisme (abad ke-4), Unitarianisme dan Christadelphian (abad ke-16 dan 18) dan Saksi Jehovah (abad ke-19).

Konsep Kristologi Penganut “ Kristen Tauhid“ yang di sebut sebagai : Tauhid merupakan sebuah kajian yang menarik. Apalagi kalangan "Kristen Tauhid " berupaya menolak Trinitas dan kelahiran Yesus Kristus. Berdasarkan fakta masalah di atas menjadi stimulus bagi penulis untuk mengadakan analisis kritis dan cermat sebagai jawaban kepada penganut Kristen Tauhid yang menolak Trinitas dan keilahian Yesus Kristus.

\section{Metode Penelitian}

Artikel ini menggunakan pendekatan kualitatif dengan metode deskriptif-analisis mengenai konsep kristologi penganut Kristen tauhid. Tujuan dari menggunakan metode ini ialah untuk menggambarkan, meringkaskan berbagai kondisi, berbagai situasi, berbagai variabel yang timbul dalam pengajaran Kristen yang menjadi objek penelitian itu, kemudian menarik ke permukaan sebagai suatu ciri atau gambaran tentang kondisi, situasi atau variabel tertentu. Pemahaman metode deskriptif yang penulis maksudkan ialah penelitian tentang konsep kristologi penganut Kristen tauhid.

\section{Hasil dan Pembahasan}

\section{Sejarah Perkembangan Ajaran "Unitarianisme" Penganut Kristen Tauhid}

Abad Permulaan, Melalui sejarah Gereja dapat dicermati bahwa yang menjadi esensi permasalahan dan perpecahan jemaat pada abad permulaan berkisar mengenai posisi Yesus 
Kristus di dalam Trinitas. Pada masa itu, banyak pemikiran-pemikiran yang menyesatkan banyak orang Kristen. Dikatakan menyesatkan karena merendahkan, meragukan, dan menyangkal Yesus Kristus sebagai pribadi kedua dari Allah Tritunggal serta sebagai Allah sejati dan Manusia Sejati. ${ }^{4}$ Orang-orang Yahudi pada zaman Tuhan Yesus sangat menekankan monotheisme, kesatuan Allah, dan penekanan ini terus dipertahankan dalam gereja Kristen. ${ }^{5}$ Akibatnya adalah bahwa sebagian orang kemudian menyingkirkan perbedaan pribadi-pribadi dalam Allah tritunggal itu satu-persatu, dan yang lain gagal dalam memberi penjelasan sempurna pada keilahian esensial dari pribadi kedua dan ketiga Allah Tritunggal. Tertullian adalah orang pertama yang memakai istilah tritunggal dan memformulasikan doktrin tersebut, tetapi masih memiliki kelemahan, sebab dalam formulasi itu ia meletakkan posisi Allah Anak di bawah Allah Bapa. ${ }^{6}$

Pada abad pertengahan, persoalan tentang doktrin trinitas dan keilahian Yesus Kristus selalu diperdebatkan, ${ }^{7}$ namun pada abad tujuh lahir aliran keagamaan yang juga hanya mengakui keesaan Allah yakni Islam. Islam menyakini bahwa Allah memiliki sifat keesaan dan ketuhanan (sebagai zat yang disembah/Al-ulluhiyah) ${ }^{8}$, oleh karena itu tidak boleh ada zat lain yang disembah . ${ }^{9}$ Sifat keesaan yang mutlak dari agama Islam didasarkan pada dakwah nabi Muhhamad yang menyatakan bahwa Dialah Allah yang esa, yang tidak beranak dan tidak diperanakkan. ${ }^{10}$ Islam juga mengenal Yesus Kristus, yang lebih dikenal dengan nama nabi Isa. Dalam konsep Islam, Yesus Kristus bukanlah Allah, namun hanya utusan Allah. Dengan demikian, Islam juga merupakan aliran keagamaan yang menolak trinitas dan ke-Allahan Yesus.

Salah satu aliran keagamaan lainnya yang muncul di luar gereja resmi pada kurun waktu abad pertengahan dikenal dengan nama Albigensianisme atau Chatarisme. ${ }^{11}$ Aliran ini juga dihubungkan dengan sekte Bogomil, yang merupakan sekte sesat di Bulgaria yang prinsip utamanya yaitu Allah memiliki dua putera, yaitu Iblis dan Kristus. ${ }^{12}$ Sebagaimana halnya Marcionisme, Albigensianisme berpegang pada konsep-konsep dualisme gnostik, sehingga aliran ini memiliki pandangan tentang adanya seorang allah terang Perjanjian Baru dan seorang allah kegelapan Perjanjian Lama. ${ }^{13}$ Mengenai pribadi Yesus Kristus, kaum Albigensianisme mengajarkan bahwa Yesus merupakan bayang-bayang atau gambaran dari Malaikat. ${ }^{14}$ Dengan

\footnotetext{
${ }^{4}$ Josapat Bangun and Juliman Harefa, "Sola Gratia Melihat Dari Status Manusia Di Hadapan Allah, Karya Penebusan Kristus, Dan Anugerah Yang Mendahului Keselamatan," SUNDERMANN: Jurnal Ilmiah Teologi, Pendidikan, Sains, Humaniora dan Kebudayaan 13, no. 2 (2020): 115-126.

${ }^{5}$ Louis Berkhof, Teologi Sistematika I, Doktrin Allah (Surabaya: Momentum, 2005), 141.

${ }^{6}$ Berkhof, Teologi Sistematika I, Doktrin Allah.

${ }^{7}$ Sonny Zaluchu, "Penderitaan Kristus Sebagai Wujud Solidaritas Allah Kepada Manusia," DUNAMIS: Jurnal Penelitian Teologi dan Pendidikan Kristiani (2017). 185-200.

${ }^{8}$ Suryan Suryan, "Toleransi Antarumat Beragama: Perspektif Islam," Jurnal Ushuluddin 23, no. 2 (2017):

${ }^{9}$ Sjaich Mahmoud Sjaitout, Islam Sebagai Aqidah \& Syariah (Jakarta: Bulan Bintang, 1972), 44.

${ }^{10}$ Hamka, Sejarah Ummat Tuhan (Jakarta: Bulan Bintang, 1975), 186.

${ }^{11}$ Ruth A. Tucker, Another Gospel (Malang: Gandum Mas, 2007), 43.

${ }^{12}$ Peter Toon J.D Douglas, Walter A. Elwell, The Consice Dictionary of The Christian Tradition (Grand Rapids, Michigan: Regency reference Library Zondervan Publishing House, 1986), 16.

${ }_{13}$ J.D Douglas (ed), The International Dictionary Of The Christian Church (Michigan: Zondervan Publishing House, 1978), 22.

${ }^{14}$ F.L Cross \& E.A Livingstone, The Oxford Dictionary of The Christian Church (Massachusetts: Modern English Press, 1989), 31.
} 
kata lain, Yesus Kristus bukanlah pribadi dari kedua Allah tritunggal, dan tidak setara dengan Allah Bapa karena hanyalah gambaran dari malaikat.

Abad Reformasi, Paham anti trinitas bangkit kembali sejalan dengan semangat reformasi Marthin Luther yang menghasilkan aliran reformasi dengan melepaskan diri dari otoritas gereja Roma Khatolik. Sejalan dengan reformasi yang dilakukan Marthin Luther, ada juga penolakan yang dilakukan sebagian orang yang mempertanyakan soal keyakinan tritunggal atau trinitas. Kelompok yang menolak paham trinitas tersebut dikenal sebagai penganut unitarianisme. Paham Unitarianisme ini dipelopori oleh beberapa tokoh, antara lain Faustus Socinus bersama pamannya, Laelus Socinus, kemudian Michael Servetus. Francis David, seorang Lutheran, di masa raja John Sigsmund (1540-1571), ikut menjadi penganut unitarian dan mempopulerkan ajaran Servetus dan Laelius Socinus yang anti-trinitarian. ${ }^{15}$ Dalam semangat reformasi, David percaya bahwa hanya Alkitab saja, khususnya empat kitab Injil pertama, adalah sumber kebenaran religius. Secara terbuka dia menyatakan bahwa doktrin Trinitas tidak punya dasar dalam Alkitab dan tidak masuk akal. Baginya, Trinitas adalah ajaran tambahan dari konsilikonsili gereja yang sangat dipengaruhi oleh filsafat Yunani populer masa itu. ${ }^{16}$

Dalam perkembangannya, kaum unitarian dicap sebagai bidat, dan kemudian banyak yang hijrah ke Polandia dan Transylvania di mana kepercayaan unitarian diterima. Kaum Unitarian belum membentuk organisasi sendiri sampai terbentuknya jemaat pertama oleh Josep Prestley dan James Martineau di Essex Street Chapel di London pada tahun 1774, dan pada tahun 1813 kaum unitarian memperoleh hak-hak mereka setelah mereka bergabung dengan beberapa kelompok pemberontak lainnya dari gereja Inggris (Church Of England). ${ }^{17}$

Pada abad pencerahan, penganut Unitarianisme semakin berkembang. Kaum unitarian menganggap agama mereka sebagai liberal yang tidak bergantung pada doktrin, keyakinan, maupun pengakuan iman tertentu, melainkan menganggap kesadaran, pengalaman, dan akal budi sebagai pondasi dalam keyakinan agama. Oleh sebab itu, mereka menekankan toleransi beragama, hakikat kebaikan manusia, dan hidup yang saling bergantung. Di Amerika Serikat, unitaraian berkembang dari perpecahan yang terjadi di kalangan pendeta gereja-gereja Puritan Konggregasional. Kelompok pendeta yang lebih liberal bereaksi terhadap doktrin predestinasi dan dosa asal dalam Calvinisme, doktrin yang melanda Protestanisme Amerika terutama semasa kebangunan besar, demikian juga konggregasi yang terpengaruh ajaran Arianisme dan Armenianisme mengarah pada ajaran Unitarian. ${ }^{18}$

Abad modern, Paham anti Trinitas terus sampai abad berkembang modern. Sekalipun bukan merupakan penganut Unitarianisme secara langsung, namun semangat unitarianisme yang anti trinitas diteruskan kembali oleh beberapa kelompok yang dengan terang-terangan menolak doktrin Trinitas dan keilahian Yesus Kristus. Beberapa kelompok anti Trinitarian yang muncul pada abad modern antara lain Saksi Jehovah, Unification Church, dan The Way International. Kemudian The Way International,_Pada tahun 1955, Wierwille membentuk

${ }^{15}$ Herlianto, Kristen Tauhid, Siapa Dan Bagaimana Ajaran Mereka? (Indonesia: Seri Buku Yabina, 2007), 10.

${ }^{16}$ Ellen Kristi, Bukan Allah Tapi Tuhan (Semarang: Borobudur Indonesia Publishing, 2008), 8.

${ }^{17}$ Herlianto, Kristen Tauhid, Siapa Dan Bagaimana Ajaran Mereka?

${ }^{18}$ Ibid. 
secara resmi badan hukum The way International. ${ }^{19}$ Wierwille memaparkan pemikirannya yang menentang doktrin Trinitas, dengan menolak keilahian Yesus Kristus dan pribadi Roh Kudus dalam sebuah buku yang berjudul Jesus Christ Is Not God (Yesus Kristus Bukan Allah). ${ }^{20}$ Dalam sebuah wawancara mengenai masalah Trinitas, ia menyatakan bahwa : "agama Kristen tidak pernah mempunyai tiga Allah. Apabila Yesus Kristus adalah Allah, dan Allah mati di kayu salib, berarti ajaran bahwa Allah itu mati adalah benar". ${ }^{21}$ Wierwille juga menegaskan bahwa Yesus Kristus bukan Allah tetapi anak Allah, ${ }^{22}$ Yesus dan Bapa tidak sama-sama kekal, tidak memiliki awal atau akhir, tidak sama derajatnya, tidak secara harafiah bersama-sama dengan Allah sedari semula dan tidak memiliki semua aset Allah, namun Yesus adalah manusia yang sempurna dan unik. ${ }^{23}$

\section{Sistem Hermeneutika Penganut Kristen Tauhid}

Bila berbicara tentang theologi, berarti menyinggung sistem hermeneutik. Maksudnya, theologi muncul karena didahului oleh sistem hermeneutik. Sudut pandang theologis seseorang dipengaruhi oleh hermeneutiknya. Karena itu, perbedaan hermeneutik paling besar kemungkinan akan membawa kepada perbedaan konsep dalam bertheologi. ${ }^{24}$ Meskipun demikian, bisa saja orang menganut sistem hermeneutik yang sama, namun tetap mencapai kesimpulan yang berbeda dalam hal doktrin sebagai akibat dari pendekatan eksegesis yang berbeda. $^{25}$

Dalam bukunya, Allah Dalam Alkitab dan Al'quran, Sesembahan yang Sama atau Berbeda?, Frans Donald menyatakan bahwa penganut Kristen Tauhid menggunakan metode kitab suci apa adanya, yakni membaca Al-Qur'an dengan metode tafsir Al-Qur'an bi AlQur'an, yaitu penafsiran ayat Al-Qur'an dengan ayat Al-Qur'an juga; membaca Alkitab dengan metode Sola Scriptura (hanya Alkitab saja) dan Scriptura interpres Scriptura (Alkitab ditafsirkan oleh Alkitab sendiri, ayat menjelaskan ayat). ${ }^{26}$ Dengan demikian, sistem penafsiran Kristen Tauhid adalah penafsiran yang kaku, berdasarkan apa yang dituliskan oleh Kitab Suci itu sendiri.

Sejalan dengan metode penafsiran kitab suci apa adanya, penganut Kristen Tauhid juga menyatakan bahwa mereka menolak pola penafsiran dengan cara berpikir Yunani. Penolakan ini dikarenakan penganut Kristen Tauhid menganggap bahwa pola berpikir Yunani bersifat metafisik dan dipengaruhi oleh filsafat-filsafat kuno dan bersifat multitafsir sehingga dapat membawa setiap pembaca Alkitab jatuh kepada penyembahan berhala dan bukannya meyakini serta menyembah Allah yang esa. ${ }^{27}$ Oleh sebab itu, penganut Kristen Tauhid dengan tegas menyatakan bahwa mereka menggunakan pola berpikir Yahudi. Bagi mereka, cara berpikir

\footnotetext{
${ }^{19}$ Irvine Robertson, What The Cult Believe (CHICAGO: Moody Press, 1983), 99.

${ }^{20}$ Ronald Enroth \& Other, A Guide To Cults and New Religions (Illinois: InterVarsity Press, 1983), 180-

${ }^{21}$ Tucker, Another Gospel.

${ }^{22}$ Other, A Guide To Cults and New Religions.

23 Tucker, Another Gospel.

${ }^{24}$ Richard Bastian Manalu, “ALKITAB DASAR PENGAJARAN,” Kerussol 2, no. 1 (2015): 17.

${ }^{25}$ Kevin J.Conner, Interpreting The Scriptures (Malang: Gandum Mas, 2004), 15.

${ }^{26}$ Frans Donald, Allah Dalam Alkitab \& Al-Qur'an, Sesembahan Yang Sama Atau Berbeda? (Semarang: Sadar Publications, 2005), 21.

${ }^{27}$ Frans Donald, Apakah Yesus Allah Sejati?, (Semarang: Sadar Publications, n.d.), 1.
} 181. 
Yahudi tidaklah multitafsir dan tidak dipengaruhi oleh filsafat-filsafat kuno yang menyesatkan. Pola berpikir monotheisme Yahudi ini mutlak digunakan karena Kitab Suci diturunkan untuk bangsa Yahudi.

\section{Konsep Kristologi Penganut Kristen Tauhid}

\section{Presuposisi Kristologis}

Presuposisi Kristologis penganut Kristen Tauhid, berawal dari hipotesa penafsiran terhadap teks Alkitab Wahyu 3:14, yang ditafsirkan dan diklaim bahwa Yesus Kristus bukan Allah, melainkan Dia adalah permulaan ciptaan Allah. Di sisi lain, mereka juga mengklaim bahwa Yesus Kristus bukanlah manusia yang biasa, seperti yang dituliskan oleh Donald : Dari perkataan Yesus dalam Alkitab yang menyatakan bahwa hanya Bapa saja satu-satunya Allah yang benar dan Yesus adalah utusan Allah (Yoh 17:3), jelas tidak bisa disangkal bahwa Yesus Kristus bukanlah Allah. Sedangkan dari kesaksian Al-Qur'an yang menyatakan bahwa Isa Almasih adalah seorang yang terkemuka di dunia dan di akhirat (Ali Imran 45), akan terlalu tergesa jika ditafsirkan bahwa Isa hanyalah manusia biasa. Jika Yesus seorang manusia biasa, tentu Dia memang bisa saja 'menjadi terkemuka di dunia', tetapi yang menjadi pertanyaan adalah apakah seorang manusia biasa bisa pula 'terkemuka di akhirat'?. Oleh sebab itu, Yesus bukanlah Allah sejati, tetapi juga bukan berasal dari manusia biasa. ${ }^{28}$ Dari penjelasan Frans Donald di atas, nampaknya penganut Kristen Tauhid mengambil jalan tengah dari ajaran Alkitab (dalam pengertian yang salah) dan Al-Qur'an dengan menyatakan bahwa Yesus Kristus bukanlah Allah sejati dan bukanlah manusia biasa, namun Dia adalah makhluk ilahi.Selain apa yang dikemukakan di atas, sebagai titik berangkat mereka dalam membangun konsep Kristologi adalah pembedaan istilah atau etimologi istilah "Allah" dan "Tuhan". Kristi menuliskan bahwa: "ada dua kata kunci untuk memahami Alkitab. Yang pertama adalah kata 'Allah' dengan variannya 'allah' dan 'ALLAH'. Yang kedua adalah 'Tuhan' dengan variannya 'tuan', 'tuhan', dan 'TUHAN'." 29 Sekalipun mereka mengakui bahwa tidak ada pembedaan huruf besar dan huruf kecil dalam bahasa Ibrani dan Yunani, presuposisi ini mereka simpulkan berdasarkan penafsiran mereka terhadap 1 Korintus 8: 4-8 dan Ulangan 10:17. Dari ayat-ayat tersebut, mereka berpendapat bahwa Allah itu Esa, berpribadi satu sehingga Yesus Kristus bukanlah Allah, melainkan Dia adalah Tuhan yang dikonotasikan sebagai orang yang dihormati. Dengan demikian, mereka menyimpulkan bahwa hanya ada satu Allah saja, yaitu Bapa, dan satu Tuhan saja, yaitu Kristus. ${ }^{30}$ Dengan demikian, dapat disimpulkan bahwa presuposisi Kristologis penganut Kristen Tauhid dapat dibagi menjadi tiga garis besar. Pertama, Yesus Kristus Bukan Allah. Kedua, Yesus Kristus adalah Tuhan ${ }^{31}$. Ketiga, Yesus Kristus bersifat ilahi.

${ }^{28}$ Frans Donald, Kasus Besar Yang Keliru, Ternyata Yesus Malaikat (Semarang: Borobudur Indonesia Publishing, 2008), 3-4.

${ }^{29}$ Kristi, Bukan Allah Tapi Tuhan.

${ }^{30}$ Ibid.

${ }^{31}$ Marthen Nainupu, "Pemuridan Melalui Pendekatan Konseling Pastoral," SOLA GRATIA: Jurnal Teologi Biblika dan Praktika 5, no. 1 (2017). 


\section{Pandangan Tentang Inkarnasi Yesus Kristus}

Penganut Kristen Tauhid mengklaim bahwa Yesus Kristus bukanlah Allah dan bukan juga manusia yang biasa, melainkan makhluk ilahi yang berinkarnasi menjadi manusia. ${ }^{32}$ Menurut mereka, lahirnya Yesus dari perawan Maria tidak boleh ditafsirkan bahwa Yesus Kristus adalah Pribadi kedua Allah Tritunggal yang berinkarnasi menjadi manusia. ${ }^{33}$ Allah hanya "menitipkan" Dia dalam rahim Maria, karena sebelum lahir sebagai manusia Yesus Kristus sudah eksis sebagai makhluk roh atau malaikat. ${ }^{34}$ Mereka berpendapat bahwa nama Yehoshua yang artinya "Allah menyelamatkan" bukanlah berarti bahwa Yesus adalah suatu makhluk hasil inkarnasi dari Allah itu sendiri, melainkan dia adalah utusan dari Allah, yang datang sebagai "agen penyelamat" mewakili Allah sang tokoh penyelamat sejati. ${ }^{35}$

Dalam menyelesaikan misinya, Yesus Kristus yang adalah malaikat Allah, harus dipandang layak mewakili manusia dalam pendamaian dengan Allah. Dia harus hidup dalam darah dan daging yang sama dengan manusia (Ibr 2:14). ${ }^{36}$ Sekalipun Yesus Kristus menjadi manusia, Ia bukanlah manusia biasa. Yesus adalah manusia ilahi yang memiliki kesempurnaan ilahi, manusia yang hidup dengan kepenuhan Allah. ${ }^{37}$ Jadi, penganut Kristen Tauhid mengklaim bahwa inkarnasi adalah lahirnya Yesus Kristus yang adalah makhluk roh, malaikat yang menjelma menjadi manusia yang bersifat ilahi, yang memiliki kesempurnaan karakter ilahi.

Selain dari Injil Yohanes 1:1, penganut Kristen Tauhid juga mengutip beberapa ayat Alkitab untuk membuktikan klaim mereka bahwa Yesus Kristus bukanlah Allah sejati, bahkan lebih rendah dari Allah Bapa. ${ }^{38}$ Mereka mengutip doa Yesus Kristus yang dituliskan dalam Yohanes 17:3, dan mengklaim bahwa Yesus Kristus adalah perantara, mediator bagi manusia untuk mengenal Allah karena Yesus Kristus memperkenalkan satu-satunya Allah yang benar, yaitu Allah Bapa yang mengutus Dia. Allah itulah yang dikenal sebagai Allah yang esa, Allah yang Tauhid, bukan Allah yang Tritunggal. ${ }^{39}$ Nugroho menjelaskan logikanya bahwa yang mengutus pasti lebih besar dari pada yang diutus, demikian juga Allah Bapa yang mengutus Yesus Kristus (bnd.Yoh 14:28), sehingga tidak mungkin jika Yesus yang adalah utusan Allah memiliki kesetaraan dengan Allah, Dia pasti lebih rendah dari Allah. ${ }^{40}$ Dengan demikian, penganut Kristen Tauhid mengklaim bahwa Yesus Kristus lebih rendah dari Allah Bapa. Atau dengan kata lain, Yesus Kristus bukanlah pribadi yang setara dengan Allah Bapa.

\section{Yesus Kristus Adalah Anak Allah, Bukan Allah Anak}

Penganut Kristen Tauhid mengklaim bahwa Yesus Kristus adalah Anak Allah, namun bukan dalam pengertian sebagai Allah Anak atau pribadi kedua Allah Tritunggal. Menurut mereka, kesalahpahaman dalam mengerti istilah anak Allah akan mengakibatkan kesalahan

\footnotetext{
${ }^{32}$ Kristi, Bukan Allah Tapi Tuhan.

${ }^{33}$ Wawancara dengan Tjahjadi Nugroho, Jakarta 2 September 2009

${ }^{34}$ Kristi, Bukan Allah Tapi Tuhan.

${ }^{35}$ Donald, Kasus Besar Yang Keliru, Ternyata Yesus Malaikat.

${ }^{36}$ Tjahjadi Nugroho, Keluarga Besar Umat Allah (Semarang: Sadar Publications, 2005), 143.

${ }^{37}$ Nugroho, Keluarga Besar Umat Allah.

${ }^{38}$ Ayat-ayat yang dikutip: Yohanes 5:23-24, 30-38; 6:29, 38, 44, 57; 7:16, 28, 29, 33, 17: 3

${ }^{39}$ Donald, Kasus Besar Yang Keliru, Ternyata Yesus Malaikat, 32.

${ }^{40}$ Wawancara dengan Tjahjadi Nugroho, Jakarta 2 September 2009
} 
theologis. ${ }^{41}$ Donald berpendapat bahwa pengertian "Anak Allah" dalam Taurat dan Injil bukanlah anak secara jasmani, melainkan secara rohani. ${ }^{42}$ Maksud dari istilah Anak Allah adalah makhluk ciptaan yang dipilih atau atau diangkat derajatnya oleh Allah. Istilah ini juga menerangkan kedekatan relasi antara sang pencipta dengan ciptaanNya, bagaikan seorang bapak dengan anaknya. Mengutip dari Matius 5: 9 yang menuliskan bahwa orang yang membawa damai akan disebut anak-anak Allah, mereka menghubungkannya dengan kreasi Kristus yang datang untuk menjadi pendamai antara Allah dan manusia. Yesus mendamaikan dosa manusia (Ibr 2:17), maka Ia layak disebut sebagai Anak Allah. ${ }^{43}$ Jadi, penganut Kristen Tauhid berpendapat bahwa Yesus Kristus bukanlah Allah Anak, melainkan Anak Allah. Pengertian bahwa Yesus Kristus adalah Anak Allah tidaklah menunjukkan bahwa hakekatNya adalah Allah, melainkan menunjukkan relasiNya yang sangat dekat dengan Allah Bapa.

\section{Yesus Kristus Adalah Malaikat Perjanjian Yang Diciptakan}

Sebagai titik berangkat klaim penganut Kristen Tauhid bahwa Yesus Kristus adalah malaikat perjanjian yang diciptakan oleh Allah adalah teks nubuatan dalam Maleakhi 3:1, yang tertulis demikian: Lihat, Aku menyuruh utusan-Ku, supaya ia mempersiapkan jalan dihadapanKu! Dengan mendadak Tuhan yang kamu cari itu akan masuk ke baitNya! Malaikat Perjanjian yang kamu kehendaki itu, sesungguhnya, Ia datang, Firman TUHAN semesta Alam. Berdasarkan ayat di atas, Nugroho menjelaskan: Dalam terjemahan The Word Of Yahweh, dikatakan The Sovereign whom ye seek, adonai yang digunakan dalam Mazmur 110:1, yaitu malaikat alhadirat-Nya atau malaikat Tuhan, masuk ke dalam baitNya. Bait bisa berarti tubuh kita (I Kor.6:19). Malaikat Perjanjian itu menjelma menjadi manusia, datang ke bumi. Sesuai kehendak Allah, malaikat itu (Roh Allah, AnakNya-Ibr 1:5-6) diturunkan ke bumi. ${ }^{44}$

Selain dari ayat-ayat yang telah dikemukakan di atas, mereka juga mengutip Keluaran 23:20-21, dan mengklaim adanya "seorang" malaikat, yang memiliki ciri-ciri yang sama dengan Yesus kristus. Pertama, bertanggung jawab atas keselamatan manusia. Kedua, sangat berkuasa dan harus dituruti serta dapat mengampuni atau menghukum dosa umatNya. Ketiga, membawa nama Allah dalam diriNya. ${ }^{45}$ Berdasarkan ciri-ciri tersebut, mereka mengklaim bahwa malaikat perjanjian tersebut adalah Yesus Kristus karena Dialah yang dapat mengampuni dosa, menyelamatkan manusia dan membawa nama Allah (Yoh. 17:11). ${ }^{46}$ Mereka mengklaim bahwa dalam menyelamatkan manusia, Allah tidak menjelma menjadi manusia, melainkan Ia berjanji untuk mengutus mal'ak (pesuruh-Nya), malaikatNya (Yes 63:9), untuk menyelamatkan manusia. ${ }^{47}$

Penganut Kristen Tauhid meyakini bahwa Yesus Kristus adalah malaikat bukan sembarang malaikat, karena Dia adalah malaikat perjanjian, utusan surgawi yang dijanjikan dan dipilih dari antara malaikat-malaikat, dari teman-temannya yang lain. Keyakinan ini

\footnotetext{
${ }^{41}$ Donald, Kasus Besar Yang Keliru, Ternyata Yesus Malaikat.

42 Ibid.

43 Ibid.

44 Tjahjadi Nugroho, Manusia Yesus Kristus (Semarang: Sadar Publications, 2005), 118.

${ }^{45}$ Nugroho, Keluarga Besar Umat Allah.

${ }^{46}$ Wawancara dengan Tjahjadi Nugroho, Jakarta 2 September 2009

${ }^{47}$ Donald, Kasus Besar Yang Keliru, Ternyata Yesus Malaikat, 114.
} 
mereka klaim berdasarkan Ibrani 1: 3-5, 9 dalam Alkitab LAI tahun 1958 dan 2004, yang diinterpretasi oleh Frans Donald demikian Teman-teman sekutu Yesus sebelum turun ke dunia adalah para makhluk surgawi alias malaikat. Hal itu cukup menjelaskan bahwa tentulah Dia yang termasuk dalam bagian kawanan para malaikat itu adalah juga berwujud malaikat. Hanya saja Ia ditinggikan melebihi teman-teman sekutunya itu...hal itu sesuai dan tepat sekali dengan kesaksian Al-Qur'an yang berbicara tentang Isa (Yesus) sebagai "Seorang yang terkemuka di dunia dan di akhirat, dekat dengan Allah" (Ali Imran QS 3:45). ${ }^{48}$ Jadi, dapat disimpulkan bahwa penganut Kristen Tauhid mengklaim bahwa Yesus Kristus adalah malaikat perjanjian yang diciptakan oleh Allah Bapa dan diutus untuk menyelamatkan umat manusia.

\section{Yesus Kristus adalah Mikhael}

Penganut Kristen Tauhid mengembangkan konsep bahwa Yesus Kristus adalah malaikat perjanjian yang diciptakan oleh Allah dengan mengklaim bahwa Yesus Kristus adalah malaikat Mikhael. Klaim bahwa Yesus Kristus adalah malaikat Mikhael ini mereka simpulkan dengan mempararelkan beberapa ayat Alkitab, yang diinterpretasi dengan melihat persamaan peran dan misi Yesus Kristus dengan Malaikat.

Persamaan pertama yang diklaim penganut Kristen Tauhid adalah Mikhael dan Yesus Kristus sama-sama mengalahkan Iblis (Why 12:7-9; bnd. Ibr 2:14). Berdasarkan kedua ayat yang dipararelkan ini, Nugroho berpendapat bahwa : "mungkinkah ada dua nama yang bersamaan menaklukkan si Iblis ini ataukah memang keduanya adalah figur yang sama dengan dua nama yang berbeda?" ${ }^{49}$ Selanjutnya, persamaan antara Mikhael dengan Yesus Kristus yang kedua yakni persamaan misi (Dan. 12:1; bnd Luk. 18:8; Mat.28:20). Nugroho kembali berpendapat bahwa: "Mikhael akan diutus Allah untuk menyertai umat yang setia pada akhir zaman, dan Yesus berjanji akan menyertai sampai akhir zaman. Dengan demikian tidak mungkinkah kedua nama itu merujuk pada satu pribadi yang sama?. ${ }^{50}$ Di sisi lain, Frans Donald, membandingkan pararel ayat-ayat Alkitab tersebut dengan ajaran Islam yang diklaimnya tercatat dalam kitab dakwah Durratun Nasihin, yang menafsirkan bahwa Yesus (Isa Almasih) adalah Arruhu, malaikat yang dijanjikan oleh Allah untuk melayani orang-orang beriman. ${ }^{51}$ Jadi, berdasarkan penafsiran dengan pararelisme ayat-ayat Alkitab, kemudian membandingkannya dengan ajaran Islam, penganut Kristen Tauhid mengklaim bahwa Yesus Kristus adalah Mikhael, malaikat perjanjian yang diciptakan Allah Bapa.

\section{Yesus Kristus Sebagai Juruselamat dan Penebus}

Menurut penganut Kristen Tauhid, Yesus Kristus diutus oleh Allah Bapa sebagai pengantara dalam rencana pendamaian manusia dengan Allah (I Yoh 2:2, I Tim 2:5 Yoh 3:16; Ibr 2:14-15; 4:14-16). ${ }^{52}$ Allah Bapa, Allah yang esa, mengutus Yesus Kristus supaya manusia bisa mendapat hikmat pengetahuan untuk memperoleh hidup kekal dan tidak binasa. Donald menyatakan bahwa Yesus Kristus telah menunjukkan pada umat manusia suatu kunci untuk

\footnotetext{
48 Ibid.

${ }^{49}$ Ibid.

${ }^{50}$ Ibid..., 140

${ }^{51}$ Donald, Kasus Besar Yang Keliru, Ternyata Yesus Malaikat.

${ }^{52}$ Nugroho, Keluarga Besar Umat Allah.
} 
mendapatkan hidup yang kekal itu dengan mengajarkan bahwa kunci untuk hidup kekal hanya ada dua. Pertama, kenal satu-satunya Allah yang benar. Kedua, kenal Yesus utsan Allah untuk mengenal Allah dengan benar, oleh sebab itu Yesuslah satu-satunya jalan dan pengantara untuk manusia bisa mencapai Allah. Mereka berpendapat bahwa melalui ketaatan Yesus Kristus yang sempurna, manusia dapat memperoleh keselamatan dengan meneladani teladan Yesus Kristus dalam melakukan kehendak Allah Bapa. Nugroho menuliskan: Inilah makna kegenapan misi Yesus Kristus di dunia. Oleh kematianNya, Ia membinasakan Iblis yang berkuasa atas maut (Ibr 2:14). Oleh kehidupanNya yang sempurna, Ia menjadi pokok keselamatan bagi manusia. ${ }^{53}$ Barang siapa percaya kepadaNya akan disempurnakan oleh Allah, seperti Dia sendiri disempurnakan oleh Allah (Ibr 2:10-11). Ia telah menerima kuasa di dunia dan akhirat, dan akan datang kembali sebagai Mesias, Hakim Adil dari Allah. ${ }^{54}$

\section{Pandangan Tentang Kematian dan Kebangkitan Yesus Kristus}

Sehubungan dengan peristiwa kematian dan kebangkitan Yesus Kristus, Donald menuliskan bahwa: "kekristenan, baik yang percaya Yesus bukan Allah sejati (kaum unitarian), maupun yang menganggap Yesus sebagai Allah sejati (kaum trinitarian), hampir semuanya sepaham dan berkeyakinan bahwa Yesus benar-benar pernah mati dan bangkit serta terangkat ke surga". ${ }^{55}$ Dari pernyataan Donald tersebut, jelas bahwa penganut Kristen Tauhid meyakini bahwa Yesus Kristus benar-benar mati dan bangkit kembali. ${ }^{56}$ Meskipun demikian, mereka berpendapat bahwa kebangkitan dari kematianNya bukanlah dari diriNya sendiri, melainkan dibangkitkan oleh Allah Bapa. ${ }^{57}$ Nugroho berpendapat bahwa kematian dan kebangkitan Yesus Kristus adalah inti Injil, yakni berita keselamatan dari Allah kepada manusia yang berdosa. Melalui keyakinan bahwa Allah Bapa telah membangkitkan Yesus Kristus yang adalah utusan Allah, mereka yakin bahwa Allah akan melakukan hal yang sama bagi setiap orang yang percaya dan melakukan kehendak Allah (Kis. 2:24; 1 Kor 6:14; Mat.7:21). ${ }^{58}$ Dengan demikian, Nugroho berpendapat bahwa oleh kematian dan kebangkitanNya, manusia dapat melihat kesetiaan Allah pada janjiNya. ${ }^{59} \mathrm{Jadi}$, penganut Kristen Tauhid meyakini peristiwa kematian dan kebangkitan Yesus Kristus, namun Dia tidak bangkit dari diriNya sendiri, karena Dia bukanlah Allah, tetapi utusan yang dibangkitkan oleh Allah Bapa.

\section{Pandangan Tentang Kedatangan Yesus Kristus Sebagai Hakim Pada Akhir Zaman}

Berkaitan dengan doktrin ini, Penganut Kristen Tauhid kembali mensintesakan ajaran Alkitab dan Al-Qur'an, yang mereka klaim memiliki hubungan yang erat dan saling melengkapi dalam mengajarkan tentang kedatangan Tuhan Yesus pada akhir zaman sebagai hakim. Penganut Kristen Tauhid mengklaim bahwa Yesus Kristus akan datang sebagai hakim pada waktu akhir zaman. Meskipun demikian, peranan sebagai hakim ini bukanlah karena Dia adalah 131.

${ }^{53}$ Ailsa Barker, “Teologi, Studi Biblika, Dan Misi,” Indonesian Journal of Theology 5, no. 1 (2017): 99-

${ }^{54}$ Donald, Kasus Besar Yang Keliru, Ternyata Yesus Malaikat.

55 Ibid., 68

${ }^{56}$ Ayat-ayat Alkitab yang dikutip: Mat 17:22-23; Kis. 2:32, 4:10, 10:40, 13:37

${ }^{57}$ Donald, Kasus Besar Yang Keliru, Ternyata Yesus Malaikat.

${ }^{58}$ Nugroho, Keluarga Besar Umat Allah.

${ }^{59}$ Ibid., 112 
Allah, namun karena Dia diberi kuasa oleh Allah Bapa (Mat. 29:18; Az Zukruf QS 43:61; An Nisa QS 4:159). Hakim yang sejati adalah Allah Bapa, namun karena Allah itu terlalu suci, maka tidak mungkin Dia menampakkan diri kepada manusia karena manusia tidak akan mampu melihat wujud asli Allah (Yoh 1:18; 5: 37, 1 Tim.6:14-16; I Yoh 4:16). Karena ketidakmampuan manusia melihat Allah, maka Allah Bapa mengirimkan utusan untuk menghakimi dunia, yaitu Yesus Kristus (Yoh 5:27-30). ${ }^{60}$ Jadi, penganut Kristen Tauhid percaya bahwa Yesus Kristus akan datang kembali sebagai Hakim. Peranan Yesus sebagai hakim bukanlah karena Dia adalah Allah, melainkan karena Dia adalah Malaikat yang diberikan kuasa oleh Allah Bapa untuk menghakimi manusia.

\section{Kesimpulan}

Identitas mereka sebagai penganut Kristen Tauhid dapat menimbulkan anggapan bahwa Kristen Tauhid merupakan salah satu aliran dari agama Kristen. Menurut penulis, identitas mereka sebagai penganut Kristen Tauhid sebenarnya tidak layak, karena ajaran mereka adalah defleksi Kristen yang menghasilkan impuritas Kristen. Theologia Kristen orthodoks tidak koheren dengan penganut Kristen Tauhid karena mempunyai keyakinan dan basis pikir berbeda serta tidak bisa ditoleransi, yakni Kristen othodoks meyakini Trinitas, sedangkan penganut Kristen Tauhid menganut unitarianisme, anti Trinitas. Theologia Penganut Kristen Tauhid adalah theologia yang bersifat sinkretisme dan mewarisi ajaran gnostik dan arianisme. Theologia yang mereka anut sesungguhnya merupakan defleksi Kristen, yang telah merusak keunikan agama Kristen. Theologia penganut Kristen Tauhid tidak dapat dipertanggung jawabkan berdasarkan Alkitab. Letak kesalahan mereka adalah dihilangkannya distansiasi cakrawala pemahaman terhadap cakrawala makna teks sehingga memutlakkan pra-sangka mereka bahwa Yesus bukan Allah. Pra-sangka tersebut mengakibatkan metode pendekatan Kristologi mereka adalah metode pendekatan dari bawah, sehingga lebih menekankan kepada segi kemanusiaan Allah. Kesalahan theologia penganut Kristen Tauhid juga timbul karena kesalahan gramatikal dan linguistik yang terjadi karena lemahnya penguasaan mereka terhadap kaidah tata bahasa Ibrani dan Yunani.

\section{Referensi}

(ed), J.D Douglas. The International Dictionary of The Christian Church. Michigan: Zondervan Publishing House, 1978.

Bangun, Josapat, and Juliman Harefa. "Sola Gratia Melihat Dari Status Manusia Di Hadapan Allah, Karya Penebusan Kristus, Dan Anugerah Yang Mendahului Keselamatan.” SUNDERMANN: Jurnal Ilmiah Teologi, Pendidikan, Sains, Humaniora dan Kebudayaan 13, no. 2 (2020): 115-126.

Barker, Ailsa. “Teologi, Studi Biblika, Dan Misi.” Indonesian Journal of Theology 5, no. 1 (2017): 99-131.

Berkhof, Louis. Teologi Sistematika I, Doktrin Allah. Surabaya: Momentum, 2005.

Donald, Frans. Allah Dalam Alkitab \& Al-Qur'an, Sesembahan Yang Sama Atau Berbeda?

${ }^{60}$ Donald, Kasus Besar Yang Keliru, Ternyata Yesus Malaikat. 
Semarang: Sadar Publications, 2005.

- Apakah Yesus Allah Sejati?,. Semarang: Sadar Publications, n.d.

- Kasus Besar Yang Keliru, Ternyata Yesus Malaikat. Semarang: Borobudur Indonesia Publishing, 2008.

Hamka. Sejarah Ummat Tuhan. Jakarta: Bulan Bintang, 1975.

Herlianto. Kristen Tauhid, Siapa Dan Bagaimana Ajaran Mereka? Indonesia: Seri Buku Yabina, 2007.

J.Conner, Kevin. Interpreting The Scriptures. Malang: Gandum Mas, 2004.

J.D Douglas, Walter A. Elwell, Peter Toon. The Consice Dictionary of The Christian Tradition.

Grand Rapids, Michigan: Regency reference Library Zondervan Publishing House, 1986.

Kristi, Ellen. Bukan Allah Tapi Tuhan. Semarang: Borobudur Indonesia Publishing, 2008.

Livingstone, F.L Cross \& E.A. The Oxford Dictionary of The Christian Church. Massachusetts: Modern English Press, 1989.

Manalu, Richard Bastian. “Alkitab Dasar Pengajaran.” Kerussol 2, no. 1 (2015): 17.

Maria Widiastuti. "Pemahaman Kristologi Bagi Guru PAK." Pendidikan Agama Kristen Vol.7 No.3 (2020): 93.

Nainupu, Marthen. "Pemuridan Melalui Pendekatan Konseling Pastoral." SOLA GRATIA: Jurnal Teologi Biblika dan Praktika 5, no. 1 (2017).

Nugroho, Tjahjadi. Keluarga Besar Umat Allah. Semarang: Sadar Publications, 2005.

- Manusia Yesus Kristustle. Semarang: Sadar Publications, 2005.

Other, Ronald Enroth \&. A Guide To Cults and New Religions. Illinois: InterVarsity Press, 1983.

Robertson, Irvine. What The Cult Believe. CHICAGO: Moody Press, 1983.

Samai, Leti Yulita, and Hendi Hendi. "Personalitas Yesus Dan Kritik Terhadap Nestorius: Analisis Ibrani 4: 12-14." SHAMAYIM: Jurnal Teologi dan Pendidikan Kristiani 2, no. 1 (2021): 14-23.

Sjaitout, Sjaich Mahmoud. Islam Sebagai Aqidah \& Syariah. Jakarta: Bulan Bintang, 1972.

Suryan, Suryan. “Toleransi Antarumat Beragama: Perspektif Islam.” Jurnal Ushuluddin 23, no. 2 (2017): 185-200.

Tucker, Ruth A. TuckerRuth A. Another Gospel. Malang: Gandum Mas, 2007.

Tumbel, Daniel. "Kristologi Dalam Injil Sinoptik." Journal Kerusso 1, no. 2 (2016): 42-56.

Zaluchu, Sonny. "Penderitaan Kristus Sebagai Wujud Solidaritas Allah Kepada Manusia." DUNAMIS: Jurnal Penelitian Teologi dan Pendidikan Kristiani (2017). 